\title{
Stroke, Cognitive Decline and Vascular Dementia: The Silent Epidemic of the 21 st Century
}

\author{
Gustavo C. Román, Editor-in-Chief
}

Twenty years ago, voices of alarm began to be heard in the health community addressing the problem of the silent epidemic of dementia in the elderly, the most common and unwanted accompaniment of increased longevity $[1,2]$. Today, Alzheimer's disease (AD) is no longer a silent problem. It has become a household name, a common condition affecting old people the world over. In most instances, $\mathrm{AD}$ is now readily recognized, accurately diagnosed and appropriately treated.

However, predictions for the future remain grim. In 1997, the prevalence of AD in the United States of America (USA) was 2.32 million (range: 1.09 to 4.58 million), with an incidence of 360,000 new cases per year [3]. Current estimates for the USA indicate that at the current rates the disease will quadruple in 50 years: by 2050 there will be between 7.98 and 12.95 million people suffering from AD [4], afflicting 1 in 45 Americans. A similar situation is occurring in developing and developed nations worldwide. A Public Health intervention that could delay the onset of AD by 2 years, would decrease by $20 \%$ the number of prevalent cases expected by 2050 [3].

The greatest hope for the prevention of AD comes from recent neuroepidemiological evidence indicating that a number of vascular risk factors appear to increase the risk of AD later in life [5, 6]. The most important vascular risk factors for AD are midlife hypertension [7-10] and diabetes mellitus [11]. The exact mechanisms of action are not clear but untreated hypertension clearly increases the risk [8]. Furthermore, the results of controlled clinical trials indicate that treatment of systolic hypertension in the elderly decreases by $50 \%$ incident cases of both vascular dementia (VaD) and $\mathrm{AD}$ [12].

Another important vascular risk factor for AD is hyperhomocysteinemia. Data from the Framingham study showed that increase in plasma homocysteine over $14 \mu \mathrm{M}$ nearly doubled the risk of $\mathrm{AD}$ [13]. Furthermore, the severity of cerebral atrophy worsens at higher concentrations of homocysteine [14-17], and with low serum folate [18].

Normally, homocysteine levels increase with age; decrease in plasma levels occurs via metabolic pathways mediated by folate, vitamin $B_{12}$ and vitamin $B_{6}$ as cofactors. Dietary supplementation with $400 \mu \mathrm{g}$ of folic acid per day decreases levels of homocysteine by $2-5 \mu \mathrm{M}$ in most subjects [19]. Of some concern is the fact that supplementation with folic acid causes a shift in dependency from folate to vitamin $B_{12}$ [20]; excessive intake of folic acid may possibly mask vitamin $\mathrm{B}_{12}$ deficiency [21].

It must be emphasized that by age 65 as many as $50 \%$ of the elderly are no longer able to absorb the vitamin $\mathrm{B}_{12}$ in food [21-24] due to lack of transcobalamin (TC). Haptocorrin and $\mathrm{TC}$ are the two main serum binding proteins for cobalamin (Cbl), but TC is responsible for delivery of the TC-Cbl complex to receptors on the cell surface of eve-

\begin{tabular}{ll}
\hline KARGER & (c) 2003 S. Karger AG, Basel \\
0251-5350/03/0223-0161\$19.50/0 \\
$\begin{array}{l}\text { Fax +4161306 1234 } \\
\begin{array}{l}\text { E-Mail karger@karger.ch } \\
\text { www.karger.com }\end{array}\end{array}$ & $\begin{array}{l}\text { Accessible online at: } \\
\text { www.karger.com/ned }\end{array}$
\end{tabular}

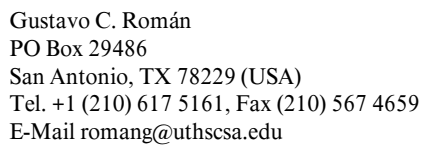


ry DNA-synthesizing cell in the human body [25]. In the elderly, therefore, dual supplementation with vitamin $B_{12}$ and folate may be required [20,22].

Since 1998, folic acid has been added to enriched grain products in the USA, primarily for prevention of neural tube defects (NTD). Fortification adds 100-240 $\mu \mathrm{g}$ of folic acid to the daily diet [26] and has resulted in a 19\% reduction of NTD prevalence in the USA [27]. Numerous other countries have recently adopted dietary fortification with folic acid [28-31].

An additional benefit of increasing folate consumption is a decrease in the risk of occlusive vascular disease and stroke associated with elevated homocysteine [22, 32, 33]. Folate improves vascular endothelial function by mechanisms probably independent of homocysteine effect in patients with coronary artery disease [34], and decreases the rate of restenosis after coronary angioplasty [35]. Homocysteine damages the endothelium by an oxidative effect; therefore, some of the protection from $\mathrm{AD}$ afforded by dietary consumption of antioxidants [36] could be mediated by prevention of the deleterious effects of hyperhomocysteinemia.

\section{Stroke and Ischemic Heart Disease: The Global Magnitude of the Problem}

Ischemic coronary artery disease (CAD) and stroke are, respectively, the two leading causes of mortality and morbidity in the elderly. The magnitude of the problem is astounding [37]: in the USA there are 12.6 million people with history of myocardial infarction (MI), angina, or both, for a prevalence of 6.3 million hospital discharges for treatment of CAD and 1 million for congestive heart failure (CHF). There are 1.1 million incident cases of MI per year and 550,000 annual cases of CHF. There are more deaths from CAD and CHF than from all forms of cancer combined. CAD is a disease of aging, showing a prevalence of $1 \%$ in the age group 50-59 years and increasing tenfold to $>10 \%$ after the age of 80 years.

Cerebrovascular disease (CVD), including stroke, is currently the second cause of death worldwide and the commonest cause of chronic disability. The frequency of CVD also rises exponentially with age. There is a 100-fold increase in stroke incidence from age 30-40 to age 80-90 (i.e., from $3 / 10,000$ to $300 / 10,000$ ) [38]. This is particularly pertinent considering that people 85 years of age and older are the fastest growing segment of the population.

According to the World Health Organization's Global Burden of Disease study [39], by the year 2020 ischemic
CAD and CVD will remain the leading non-infectious causes of disease burden in adults, as measured in DALYs (Disability Adjusted Life Years). Hypertension, tobacco and physical inactivity appear to be the main preventable risk factors [39].

\section{Stroke, CVD and CAD Causing VaD: The Incoming Silent Epidemic}

Although the impact of CAD and CVD as major causes of death and physical disability are readily recognized, their contributions to cognitive dysfunction and dementia are almost totally unrecognized. For instance, post-stroke dementia, also known as multi-infarct dementia when it develops as a result of multiple strokes, affects about $30 \%$ of patients older than 65 years after ischemic stroke [4042]. This means that in the United States alone, the incidence of post-stroke $\mathrm{VaD}$ is approximately 125,000 new cases per year (about 1/3 of the estimated 360,000 incident cases of AD). In Europe, an estimated 2,700,000 persons have suffered at least one stroke, with 536,000 new stroke cases per year [43] for an estimated incidence of 140,000 annual cases of post-stroke $\mathrm{VaD}$. It is anticipated that the figure for Latin America and Japan would be at least similar or higher [44]. A recent study from the Rotterdam cohort [45], demonstrated the importance of silent strokes as RFs for dementia in the elderly. Silent, subcortical strokes, particularly in the thalamus, produced significant cognitive decline and more than doubled the risk of dementia (hazard ratio, 2.26; 95\% confidence interval, 1.09 to 4.70 ).

Hypoperfusion from CHF is being increasingly recognized as a significant factor for cognitive decline in the elderly. A large study recently demonstrated cognitive impairment in $26 \%$ of patients discharged from the hospital after treatment of CHF [46]. Worse cognitive function occurred in cases with poor left ventricular function and lower systolic blood pressure, indicating that cerebral hypoperfusion is an important factor [47] in this cardiogenic form of $\mathrm{VaD}$, although $\mathrm{CHF}$ also increases the risk for cerebral embolism. Other populations at risk of unrecognized $\mathrm{VaD}$ include patients post coronary artery bypass graft (CABG), as well as those in cardiac rehabilitation facilities and in convalescence services after major surgery, in particular following hip fracture repair and knee replacement. It has been predicted that $\mathrm{VaD}$ resulting from CAD, CHF and CVD may be the most common form of dementia in the elderly [48]. This will become, most certainly, the silent epidemic of the 21 st century. 
In keeping with the importance of the problem, this issue of Neuroepidemiology is devoted in its entirety to stroke, presenting articles from widely separated areas of the world: Brazil, Malaysia, and Finland, also including a study of post-stroke cognitive decline and $\mathrm{VaD}$ from Sydney, Australia [49]. Finally, an important article by Ingles and her colleagues from the Canadian Study on Health and Aging [50] points to the importance of appropriate neuropsychological tests in the elderly in order to recognize the presence of underlying cognitive decline and dementia.

Control of cardiovascular risk factors is probably our best chance of fighting AD and the incoming epidemic of $\mathrm{VaD}$. However, it must be remembered that prevention of dementia must begin no later than midlife.

\section{References}

1 Kushnir SL: Reflections on Alzheimer's disease. Can J Psychiatry 1982;27:18-22.

2 Beck JC, Benson DF, Scheibel AB, Spar JE, Rubenstein LZ: Dementia in the elderly: the silent epidemic. Ann Intern Med 1982;97:231241.

3 Brookmeyer R, Gray S, Kawas C: Projections of Alzheimer's disease in the United States and the public health impact of delaying disease onset. Am J Public Health 1998;88:13371342.

4 Sloane PD, Zimmerman S, Suchindran C, Reed P, Wang L, Boustani M, Sudha S: The public health impact of Alzheimer's disease, 2000-2050: potential implication of treatment advances. Annu Rev Public Health 2002;23: 213-231.

5 de la Torre JC: Alzheimer disease as a vascular disorder: nosological evidence. Stroke 2002;33: 1152-1162.

6 Iadecola C, Gorelick PB: Converging pathogenic mechanisms in vascular and neurodegenerative dementia. Stroke 2003;34:335-337.

7 Skoog I, Gustafson D: Hypertension and related factors in the etiology of Alzheimer's disease. Ann N Y Acad Sci 2002;977:29-36.

8 Launer LJ, Ross GW, Petrovitch H, Masaki K, Foley D, White LR, Havlik RJ: Midlife blood pressure and dementia: the Honolulu-Asia aging study. Neurobiol Aging 2000;21:49-55.

9 Launer LJ: Demonstrating the case that AD is a vascular disease: epidemiologic evidence. Ageing Res Rev 2002;1:61-77.

10 Breteler MM: Vascular risk factors for $\mathrm{Alz}$ heimer's disease: an epidemiologic perspective. Neurobiol Aging 2000;21:153-160.

11 Peila R, Rodriguez BL, Launer LJ for the Honolulu-Asia Aging Study: Type 2 diabetes, APOE gene, and the risk for dementia and related pathologies: The Honolulu-Asia Aging Study. Diabetes 2002;51:1256-1262.

12 Forette F, Seux ML, Staessen JA, Thijs L, Babarskiene MR, Babeanu S, Bossini A, Fagard R, Gil-Extremera B, Laks T, Kobalava Z, Sarti C, Tuomilehto J, Vanhanen H, Webster J, Yodfat Y, Birkenhager WH for the Systolic Hypertension in Europe Investigators: The prevention of dementia with antihypertensive treatment: New evidence from the Systolic Hypertension in Europe (Syst-Eur) study. Arch Intern Med 2002;162:2046-2052.
13 Seshadri S, Beiser A, Selhub J, Jacques PF, Rosenberg IH, D'Agostino RB, Wilson PW, Wolf PA: Plasma homocysteine as a risk factor for dementia and Alzheimer's disease. N Engl J Med 2002;346:476-483.

14 den Heijer T, Vermeer SE, Clarke R, Oudkerk M, Koudstaal PJ, Hofman A, Breteler MM: Homocysteine and brain atrophy on MRI of non-demented elderly. Brain 2003;126:170175.

15 Bleich S, Bandelow B, Javaheripour K, Muller A, Degner D, Wilhelm J, Havemann-Reinecke U, Sperling W, Ruther E, Kornhuber J: Hyperhomocysteinemia as a new risk factor for brain shrinkage in patients with alcoholism. Neurosci Lett 2003;335:179-182.

16 Williams JH, Pereira EA, Budge MM, Bradley KM: Minimal hippocampal width relates to plasma homocysteine in community-dwelling older people. Age Ageing 2002;31:440-444.

17 Sachdev PS, Valenzuela M, Wang XL, Looi JC, Brodaty H: Relationship between plasma homocysteine levels and brain atrophy in healthy elderly individuals. Neurology 2002;58:15391541.

18 Snowdon DA, Tully CL, Smith CD, Riley KP, Markesbery WR: Serum folate and the severity of atrophy of the neocortex in Alzheimer disease: findings from the Nun study. Am J Clin Nutr 2000;71:993-998.

19 Jacques PF, Selhub J, Bostom AG, Wilson PW, Rosenberg IH: The effect of folic acid fortification on plasma folate and total homocysteine concentrations. N Engl J Med 1999;340:1449_ 1454.

20 Quinlivan EP, McPartlin J, McNulty H, Ward M, Strain JJ, Weir DG, Scott JM: Importance of both folic acid and vitamin B12 in reduction of risk of vascular disease. Lancet 2002;359: 227-228.

21 Weir DG, Scott JM: Brain function in the elderly: role of vitamin B12 and folate. Br Med Bull 1999;55:669-682.

22 Flynn MA, Herbert V, Nolph GB, Krause G: Atherogenesis and the homocysteine-folate-cobalamin triad: do we need standardized analyses? J Am Coll Nutr 1997; 16:258-267.

23 Balk HW, Russel RM: Vitamin B12 deficiency in the elderly. Annu Rev Nutr 1999;19:357377.
24 Johnson MA, Hawthorne NA, Brackett WR, Fischer JG, Gunter EW, Allen RH, Stabler SP: Hyperhomocysteinemia and vitamin B-12 deficiency in elderly using Title IIIc nutrition services. Am J Clin Nutr 2003;77:211-220.

25 Ulleland M, Eilertsen I, Quadros EV, Rothenberg SP, Fedosov SN, Sundrehagen E, Örning $\mathrm{L}$ : Direct assay for cobalamin bound to transcobalamin (Holo-Transcobalamin) in serum. Clin Chem 2002;48:526-532.

26 Quinlivan EP, Gregory JF: Effect of food fortification on folic acid intake in the United States. Am J Clin Nutr 2003;77:221-225.

27 Honein MA, Paulozzi LJ, Mathews TJ, Erickson JD, Wong LY: Impact of folic acid fortification of the US food supply on the occurrence of neural tube defects. JAMA 2001;285:29812986.

28 Adams T, Jeffreson S: Australia implements voluntary folate fortification. Am J Public Health 1996;86:593-594.

29 Health Canada. Food and drug regulations, Amendment Schedule no. 1066. Ottawa: Health Canada, 1997.

30 Freire WB, Hertrampf E, Cortes F: Effect of folic acid fortification in Chile: preliminary results. Eur J Pediatr Surg 2000;10 (Suppl 1):42-43.

31 Committee on Medical Aspects of Food and Nutrition Policy (COMA): Folic acid and the prevention of disease. London, England: Department of Health, 2000.

32 Homocysteine Studies Collaboration: Homocysteine and risk of ischemic heart disease and stroke: a meta-analysis. JAMA 2002;288: 2015-2022.

33 Eikelboom JW, Lonn E, Genest J Jr, Hankey G, Yusuf S: Homocyst(e)ine and cardiovascular disease: a critical review of the epidemiologic evidence. Ann Intern Med 1999;131:363375.

34 Doshi SN, McDowell IF, Moat SJ, Payne N, Durrant HJ, Lewis MJ: Folic acid improves endothelial function in coronary artery disease via mechanisms largely independent of homocysteine lowering. Circulation 2002;105:2226.

35 Schnyder G, Roffi M, Pin R, Flammer Y, Lange H, Eberli FR, Meier B, Turi ZG, Hess OM: Decreased rate of coronary restenosis after lowering of plasma homocysteine levels. N Engl J Med 2001;345:1593-1600. 
36 Engelhart MJ, Geerlings MI, Ruitenberg A, van Swieten JC, Hofman A, Witteman JC, Breteler MM: Dietary intake of antioxidants and risk of Alzheimer disease. JAMA 2002;287: 3223-3229.

37 American Heart Association: 2002 Heart and Stroke Update, www.americanheart.org 2003.

38 Bonita R: Epidemiology of stroke. Lancet 1992;339:342-344.

39 Murray CJL, Lopez AD: Global mortality, disability, and the contribution of risk factors: Global Burden of Disease Study. Lancet 1997; 349:1436-1442.

40 Pohjasvaara T, Erkinjuntti T, Vataja R, Kaste $\mathrm{M}$ : Dementia three months after stroke. Baseline frequency and effect of different definitions of dementia in the Helsinki Stroke Aging Memory Study (SAM) cohort. Stroke 1997;28: 785-792.

41 Barba R, Martinez-Espinosa S, Rodriguez-Garcia E, Pondal M, Vivancos J, Del Ser T: Poststroke dementia : clinical features and risk factors. Stroke 2000;31:1494-1501.
42 Desmond DW, Moroney JT, Sano M, Stern Y: Incidence of dementia after ischemic stroke: results of a longitudinal study. Stroke 2002;33: 2254-2260.

43 DiCarlo A, Launer LJ, Breteler MMB, Fratiglioni L, Lobo A, Martinez-Lage J, et al: Frequency of stroke in Europe: A collaborative study of population-based cohorts. Neurology 2000;54(suppl 5):S28-33.

44 Dubois MF, Hebert R: The incidence of vascular dementia in Canada: a comparison with Europe and East Asia. Neuroepidemiology 2001;20:179-187.

45 Vermeer SE, Prins ND, den Heijer T, Hofman A, Koudstaal PJ, Breteler MMB: Silent brain infarcts and the risk of dementia and cognitive decline. N Engl J Med 2003;348:1215-1222.
46 Zuccalà G, Onder G, Pedone C, Carosella L, Pahor M, Bernabei R, Cocchi A, for the GIFAONLUS Study Group [Grupo Italiano di Farmacoepidemiologia nell'Anziano]: Hypotension and cognitive impairment: Selective association in patients with heart failure. Neurology 2001;57:1986-1992.

47 Pullicino PM, Hart J: Cognitive impairment in congestive heart failure? Embolism vs hypoperfusion. Neurology 2001;57:1945-1946.

48 Román GC: Vascular dementia may be the most common form of dementia in the elderly. J Neurol Sci 2002;203-204:7-10.

49 Piguet O, Grayson DA, Creasey H, Bennett HP, Brooks WS, Waite LM, Broe AG: Vascular risk factors, cognition and dementia incidence over 6 years in the Sydney Older Persons Study. Neuroepidemiology 2003;22:165-171.

50 Ingles JL, Fisk JD, Merry HR, Rockwood K: Five-year outcomes for dementia defined solely by neuropsychological test performance. Neuroepidemiology 2003;22:172-178. 